\title{
PEMBERDAYAAN IBU-IBU JAMAAH MAJELIS TA'LIM MELALUI PELATIHAN KEWIRAUSAHAAN SYARI'AH DI DESA BALOKANG KOTA BANJAR PROPINSI JAWA BARAT
}

\author{
Hasan Bisri ${ }^{1)}$, Cucu Setiawan ${ }^{2)}$ \\ 1) Jurusan Tafsir dan Hukum Islam, Fakultas Pascasarjana UIN Sunan Gunung Djati Bandung \\ ${ }^{2)}$ Fakultas Ushuludin UIN Sunan Gunung Djati Bandung, email : cucusetiawantea@yahoo.com
}

\begin{abstract}
Abstrak
Pengabdian kepada masyarakat dengan menggunakan metode participatory action research (PAR) ini menawarkan program pelatihan kewirausahaan Syari'ah. Kegiatan yang dilakukan di Desa Balokang Kota Banjar Propinsi Jawa Barat ini berhasil meningkatkan pengetahuan, pemahaman, dan wawasan ibu-ibu jamaah Majelis Ta'lim tentang seluk beluk ekonomi Syari'ah, sehingga mereka memiliki kesadaran untuk bermu'amalah secara syari'ah.. .
\end{abstract}

Kata Kunci: Banjar, kewirausahaan Syari’ah,Participatory action research (PAR).

\begin{abstract}
Community service using the participatory action research (PAR) method offers a Shari'ah entrepreneurship training program. The activity carried out in Balokang Village, Banjar City, West Java Province succeeded in increasing the knowledge, understanding, and insights of the assembly members of the Assembly of Ta'lim about the Shari'ah economic theory, so that they have an awareness to do it in Shari'ah.
\end{abstract}

Keywords: Banjar,article, Participatory action research (PAR),Syari'ah entrepreneurship.

\section{PENDAHULUAN}

Kegiatan yang dilakukan di Desa Balokang Kota Banjar Propinsi Jawa Barat ini berhasil meningkatkan pengetahuan, pemahaman, dan wawasan ibu-ibu jamaah Majelis Ta'lim tentang seluk beluk ekonomi Syari'ah, sehingga mereka memiliki kesadaran untuk bermu'amalah secara syari'ah. Kata-Kata Kunci: Participatory action research (PAR), pelatihan kewirausahaan Syari'ah A.

Pendahuluan Pengabdian kepada masyarakat pada instinya adalah pengembangan atau pemberdayaan masyarakat (community development). Pada umumnya, pengembangan masyarakat dimaknai sebagai suatu proses di mana anggota masyarakat bersatu untuk mengambil tindakan kolektif dan menghasilkan solusi untuk masalahmasalah umum.

Ini adalah istilah luas yang diberikan kepada kegiatan para akademisi, pemimpin sosial, aktivis, warga yang terlibat, atau kaum profesional untuk meningkatkan berbagai aspek komunitas, biasanya bertujuan untuk membangun komunitas lokal yang lebih kuat dan lebih tangguh. Secara profesional, pengembangan masyarakat juga dipahami sebagai aktivitas berbasis latihan atau praktik dan disiplin akademik yang mempromosikan kegiatan partisipatif, pembangunan berkelanjutan, penyadaran hak, pengembangan peluang ekonomi, kesetaraan dan keadilan sosial, yang dilakukan melalui pengorganisasian, pendidikan, pelatihan, dan pemberdayaan orang-orang dalam komunitas mereka, baik di daerah perkotaan maupun pedesaan.

Pengembangan masyarakat berupaya untuk memberdayakan setiap individu dan komunitas dengan keterampilan yang mereka perlukan untuk menghasilkan perubahan dalam komunitas mereka. Keterampilan ini sering dikembangkan melalui pembentukan kelompok sosial yang bekerja untuk agenda bersama. Para pengabdi atau pengembang komunitas harus memahami cara bekerja bersama-sama dengan individu dan bagaimana memengaruhi kedudukan masyarakat dalam konteks institusi sosial yang lebih besar.

Prinsip penting dalam pengembangan atau pemberdayaan (empowerment) masyarakat adalah adanya pelibatan atau pemberdayaan masyarakat dalam program yang dilaksanakan. Pelibatan masyarakat dimulai dari proses perencanaan, pengorganisasian, pelaksanaan, evaluasi, dan tindak lanjut. Pengembangan atau pemberdayaan masyarakat memiliki tiga karakteristik utama, yaitu berbasis komunitas (community based), berbasis sumber daya setempat (local resource based), dan berkelanjutan (sustainable). Pengembangan atau pemberdayaan masyarakat mengandalkan peran serta dan kekuatan masyarakat.

Karenanya, dalam proses pengembangan atau pemberdayaan masyarakat, pengembang atau pengabdi 
perlu mengidentifikasi potensi kekuatan sumber daya masyarakat karena hal itu dapat menjadi salah satu bentuk konkret peran serta dan kontribusi dari masyarakat. Adanya peran serta inilah yang akan menjadi jaminan bahwa program tersebut dapat berkelanjutan bahkan ketika program telah dihentikan.

Dalam konteks pendidikan tinggi di Indonesia, pengembangan masyarakat adalah bagian dari implementasi tri dharma pendidikan tinggi, di mana setiap sivitas akademika, khususnya dosen dan mahasiswa, memiliki kewajiban untuk menerapkan aktivitas ilmiahnya di tengah masyarakat untuk bersama-sama membangun dan memberdayakan masyarakat. Kegiatan Pengabdian pada Masyarakat oleh Dosen Klaster Lokasi KKN adalah: 'Pemberdayaan Ibu-Ibu Jamaah Majelis Ta'lim Melalui Pelatihan Kewirausahaan Syari'ah di Desa Balokang Kota Banjar Propinsi Jawa Barat”.

\section{KAJIAN TEORI}

\section{METODOLOGI PENGABDIAN}

Metode kegiatan yang digunakan adalah metode participatory action research (PAR), yang pada umumnya metode ini terbagi dalam dua jenis, yakni eksplanatif dan tematik.

PAR eksplanatif memfasilitasi masyarakat untuk berperan dan berpartisipasi dalam menganalisis permasalahan, kebutuhan, dan solusinya sebelum melakukan aksi transformatif. Adapun PAR tematik mengembangkan program aksi transformatif yang sudah berjalan, sebagai instrumen evaluasi dan pengamatan (monitoring). PAR dilengkapi dengan banyak metode dan alat kerja.

Untuk mengumpulkan data di lapangan, mengolahnya, dan menganalisisnya, PAR menggunakan metode berbagi cerita (sharing), wawancara mendalam (in-depth interview), serta diskusi kelompok terfokus (focus group discussion/FGD). Dalam FGD, partisipan atau peserta tidak hanya berdiskusi dalam posisi duduk, akan tetapi dapat berdiskusi sesuai dengan dinamika tertentu dengan menggunakan instrumen kerja tertentu, seperti pemetaan gagasan (mind mapping), grafik pohon masalah (problem tree), grafik kecenderungan (trend lines), matriks ranking atau skala prioritas, dan lain-lain. Bahkan, penggalian informasi dari partisipan bisa dilakukan melalui permainan peran (role-play).

Dalam dinamika seperti itu, partisipan atau peserta memiliki kesempatan lebih besar untuk mengungkapkan pengalaman, problematika, gagasan, dan refleksi mereka secara lebih transparan karena terbantu oleh alat-alat kerja yang memudahkan pengamatan secara visual dan kegiatan yang dinamis, fleksibel, dan tidak kaku. Dengan pola dinamika seperti itu, maka akan memudahkan fasilitator untuk mendorong soptimal mungkin partisipan, seperti, atau informan untuk berperan dan berpartisipasi lebih aktif karena menggunakan aktivitas dan alat perangkat kerja yang dapat dipilih atas pertimbangan kesesuaiannya dengan background pendidikan, kultur, dan pekerjaan partisipan, peserta, atau informan.

Kegiatan ini dipandang berhasil apabila indikatorindikator di bawah ini tercapai. Indikator-indikator tersebut adalah:

1. Masyarakat memiliki wawasan dan pengetahuan ekonomi syari'ah

2. Masyarakat menjadi lebih berdaya dengan wawasan dan kompetensi baru.

3. Masyarakat memiliki kemampuan mengakses sumbers-sumber pembiayaan ekonomi syari'ah.

4. Masyarakat memiliki kompetensi di bidang kewirausahaan berbasis syari'ah.

5. Masyarakat memiliki kemampuan memasarkan produk secara syari'ah.

6. Masyarakat memiliki kemampuan membangun jaringan (networking).

\section{PELAKSANAAN KEGIATAN}

Kegiatan PkM ini dilaksanakan di Desa Balokang Kota Banjar Propinsi Jawa Barat. Desa Balokang adalah salah satu desa yang berada di Kota Banjar.

Nama Balokang secara singkat dilatarbelakangi pada jaman di era Kerajaan Sukapura Tasikmalaya pada tahun 1840 yang pada waktu itu Bupatinya adalah Rd. Tumenggung Sunardja, dan Kepala Desa Balokang yang pertama pada itu itu dijabat oleh Rd. Wirasantana atau yang lebih dikenal dengan panggilan "Kuwu Bintang" karena keberhasilan beliau dalam membangun dan memimpin masyarakat sehingga atas kesuksesannya tersebut beliau mendapatkan bintang penghargaan.

Pada waktu itu, kebanyak masyarakat Desa Balokang berprofesi sebagai petani atau pekebun kelapa dengan hasil andalannya tentu saja buah kelapa. Nama Balokang itu sendiri berasal dari nama bagian pohon kelapa yaitu pelepah atau balukang (bahasa Sunda Barangbang). Suatu bagian pohon kelapa yang pada waktu itu sangat banyak sekali dan berserakan di desa tersebut.

Saking banyaknya pelepah/balukang yang berserakan di desa tersebut sehingga oleh masyarakat sering disebut Desa Balokang sehingga akhirnya nama tersebut disepakati menjadi nama resmi desa. Adapun wilayah Desa Balokang pada waktu itu meliputi batas sebelah utara adalah sungai Citanduy Kec. Cisaga Kab. Ciami; batas sebelah timur adalah kelurahan Banjar; batas sebelah selatan adalah desa Neglasari; batas sebelah barat adalahDesa Jajawar dan Desa Cibeureum. 


\section{HASIL DAN PEMBAHASAN}

Jumlah penduduk Desa Balokang sebanyak 8.629 jiwa yang terdiri dari 4.311 orang laki-laki dan 4.318 orang perempuan serta terdiri atas 2.558 kepala keluarga. Jumlah penduduk miskin sebanyak 2.605 orang. Dari aspek pendidikan penduduk usia 3 - 6 tahun yang belum masuk TK sebanyak 732 orang; usia $3-6$ tahun yang sedang TK/play group sebanyak 563 orang; usia 7 - 18 tahun yang tidak pernah sekolah sebanyak 161 orang; usia 7 - 18 tahun yang sedang sekolah sebanyak 2.252 orang; tamat SD/MI/sederajat sebanyak 2.442 orang; tamat SMP/MTs/sederajat sebanyak 923 orang; tamat SMA/MA/SMK sederajat sebanyak 833 orang; tamat D-1 sebanyak 152 orang; tamat D-2 sebanyak 129 orang; tamat D-3 sebanyak 119 orang; tamat S-1 sebanyak 176 orang; tamat S-2 sebanyak 86 orang; tamat S-3 sebanyak 23 orang; tamat SLB-A sebanyak 14 orang; dan tamat SLB-B sebanyak 24 orang.

Dari aspek mata pencaharian penduduk Desa Balokang dapat dideskripsikan sebagai berikut: Mata pencaharian petani sebanyak 204 orang; buruh tani sebanyak 708 orang; PNS sebanyak 252 orang; pengerajn industri rumah tangga sebanyak 75 orang; peternak sebanyak 36 orang; pedagang keliling sebanyak 225 orang; montir sebanyak 7 orang; bidan swasta sebanyak 5 orang; pembantu rumah tangga sebanyak 26 orang; TNI sebanyak 6 orang; Polri sebanyak 6 orang; pensiunan PNS/TNI/Polri sebanyak 102 orang; pengusaha kecil dan menengah sebanyak 307 orang; dukun kampung terlatih sebanyak 5 orang; seniman sebanyak 10 orang; honorer sebanyak 163 orang; BUMN sebanyak 90 orang; belum/tidak bekerja sebanyak 2.070 orang; pelajar/mahasiswa sebanyak 1.165; orang ibu rumah tangga sebanyak 3.030 orang; BUMD sebanyak 31 orang; transportasi sebanyak 71 orang; penjahit sebanyak 19 orang; mekanik sebanyak 16 orang.

Dari segi keagamaan penganut agama Islam sebanyak 8.613 orang dan penganut Kristen sebanyak 16 orang. Adapun dari aspek etnis etnis sunda sebanyak 8.472 orang; etnis Jawa sebanyak 129 orang; Batak sebanyak 16 orang; Madura sebanyak 2 orang; Padang sebanyak 8 orang; Lombok sebanyak 2 orang. Dari data-data tersebut tampak bahwa Desa Balokang masih memerlukan usaha serius untuk mengembangkan potensi yang ada untuk meningkatkan kesejahteraan penduduknya.

Dengan jumlah miskin sebanyak 2.605 orang; desa Balokang masih perlu diberdayakan dengan menggali potensi yang ada di desa ini serta potensi di desa-desa sekitarnya.

\section{Kegiatan Pra-Pemberdayaan}

Dengan jumlah miskin sebanyak 2.605 orang kegiatan pengabdian pada masyarakat ini tentu saja tidak akan menjadikan semuanya sebagai sasaran kegiatan ini.
Sasaran pengabdian kepada masyarakat ini adalah ibuibu jamaah Majelis Ta'lim di Desa Balokang melalui kegiatan 'Pemberdayaan Ibu-Ibu Jamaah Majelis Ta'lim Melalui Pelatihan Kewirausahaan Syari'ah di Desa Balokang Kota Banjar Propinsi Jawa Barat”. Masalahmasalah yang berhasil diidentifikasi di lokasi pengabdian pada masyarakat ini adalah sebagai berikut:

1. Masih tingginya angka kemiskinan penduduk.

2. Potensi Desa Balokang belum digali dan dikembangkan secara optimal untuk kesejahteraan masyarakat.

3. Wawasan wirausaha masyarakat masih rendah Pengetahuan dan pemahaman di bidang wirausaha berbasis Syari'ah masih rendah.

4. Masih tingginya angka pengangguran pada usia produktif

5. Lembaga-lembaga keagamaan (dakwah dan pendidikan) belum diintegrasikan dengan upaya pengembangan ekonomi masyarakat.

Kerangka pemecahan masalah dalam kegiatan Pemberdayaan Ibu-Ibu Jamaah Majelis Ta'lim Melalui Pelatihan Kewirausahaan Syari'ah di Desa Balokang Kota Banjar Propinsi Jawa Barat dilakukan melalui tahap-tahap kegiatan berikut penyadaran, menunjukkan, membantu memecahkan masalah, menunjukkan pentingnya perubahan, melakukan pengujian, melaksanakan pemberdayaan, dan evaluasi.

Penyadaran, yaitu kegiatan-kegiatan yang dilaksanakan untuk memberikan penyadaran kepada masyarakat tentang keberadaannya, baik keberadaannya sebagai pribadi dan anggota komunitas, maupun dalam hubungannya dengan kondisi lingkungan fisik, sosial-budaya, ekonomi, dan politik. Hal itu menunjukkan adanya masalah, yaitu kondisi yang tidak sesuai dengan cita-cita dan keinginan yang kaitannya dengan keadaan sumber daya alam, sumber daya manusia sarana-prasarana, kelembagaan, budaya, dan aksebilitas, serta lingkungan fisik, sosial-budaya, dan politis.

Membantu pemecahan masalah, melalui analisis akar permasalahan dan analisis alternatif problem solving, serta pilihan sejumlah alternatif pemecahan terbaik yang dapat dilakukan sesuai kondisi internal (kekuatan, kelemahan) maupun kondisi eksternal (peluang, ancaman) yang dihadapi. Hal itu menunjukkan pentingnya perubahan, yang akan dan sedang terjadi di lingkungannya, baik lingkungan organisasi dan masyarakat maupun lingkup nasional, regional, dan global.

Melakukan pengujian dan demonstrasi, yang merupakan bagian dan implementasi perubahan yang direncanakan yang berhasil dirumuskan. Memproduksi dan publikasi informasi, baik yang datang dari "luar" (penelitian, kebijakan, produsen/pelaku bisnis) maupun yang bersumber dari dalam (pengalaman, indigenous 
technology, maupun kearifan tradisional dan nilai-nilai adat yang lain).

Melaksanakan pemberdayaan/atau penguatan kapasitas, yaitu pemberian kesempatan pada kelompok lapisan bawah (grass root) untuk bersuara dan menetapkan sendiri pilihan-pilihannya (voice and choice) dalam kaitannya dengan aksesibilitas informasi, keterlibatan dalam pemenuhan kebutuhan, serta partisipasi dalam keseluruhan proses pengembangan dan pembangunan, bertanggung jawab (akuntabilitas publik), dan penguatan kapasitas lokal.

\section{Pelaksanaan Kegiatan Pemberdayaan}

Kegiatan pemberdayaan dilakukan dengan melakukan penyuluhan tentang pentingnya pengembangan dan kesadaran ber-ekonomi secara syari'ah kepada Ibu-Ibu Jamaah Majelis Ta'lim di Desa Balokang Kota Banjar Propinsi Jawa Barat. Kegiatan penyuluhan ini dilaksanakan pada bulan November 2018. Kegiatan penyuluhan ini diarahkan untuk membangun kesadaran berekonomi syari'ah serta memberdayakan Ibu-Ibu Jamaah Majelis Ta'lim melalui Ekonomi Syari'ah.

Sesuai dengan karakteristik Ibu-Ibu Jamaah Majelis Ta'lim di desa ini, sebagian besar dari mereka adalah warga kelas menengah ke bawah, sebagian besar masih memiliki usaha di sektor riil dalam skala kecil dan memerlukan bantuan modal dari pihak ketiga untuk mengembangkan kegiatan usahanya. Sayangnya, akses untuk memperoleh pendanaan dan modal masih sangat terbatas.

Seringkali, kondisi tersebut menjadi sasaran empuk "Bank Keliling" atau rentenir untuk mencari untung berlipat. Akibatnya tidak sedikit dari masyarakat yang harus mengalami dampak negatif yang berkepanjangan akibat terperangkap oleh "Bank Keliling" atau rentenir tersebut. Kegiatan penyuluhan ini berupaya untuk menawarkan penerapan ekonomi Syari'ah di wilayah ini sekaligus mencari solusi dalam mengatasi masalah permodalan ini adalah dengan membentuk lembaga keuangan mikro Syari'ah (LKM Syariah), seperti BMT atau koperasi syari'ah.

Pembentukan koperasi Syari'ah ini diarahkan agar dilakukan secara swadaya dan mandiri tanpa menginduk kepada lembaga keuangan/perbankan Syari'ah yang sudah besar. Pembentukan koperasi Syari'ah ini diharapkan mampu memberikan pelayanan penerima pembiayaanan modal untuk sektor riil dengan sistem syirkah (kerjasama) dan menggunakan prinsip dari rakyat, dilaksanakan oleh rakyat, dan didayagunakan untuk rakyat.

Dalam penyuluhan ini juga dilakukan persiapan pembentukan koperasi Syari'ah dengan melalui tahapantahapan sebagai berikut: Pertama, penentuan kader-kader pengurus. kader-kader pengurus koperasi Syari'ah harus berasal dari masyarakat itu sendiri. Hal utama yang harus dimiliki calon kader pengurus koperasi Syari'ah adalah komitmen untuk menjalankan amanah karena pembentukan koperasi Syari'ah ini tidak mengorientasikan untuk mencari keuntungan melainkan untuk meningkatkan kesejahteraan masyarakat dengan membantu permodalan dalam usaha mereka.

Selain itu, para calon kader pengurus harus memiliki kompentensi yang lebih dibanding yang lain. Kedua, penyusunan sistem/mekanisme/teknis pelaksanaan koperasi Syari'ah. Setelah kader-kader pengurus ada dan dipandang siap untuk memegang amanah, seluruh kader melakukan pertemuan atau rapat untuk menentukan cara dan mekanisme atau teknis kerja, mulai dari bagaimana cara pengumpulan dana hingga menyalurkannya kepada masyarakat.

Selain itu, dalam pertemuan dan rapat kerja tersebut, semua kader pengurus harus terlebih dahulu menetapkan batas wilayah yang akan menjadi sasaran kegiatan operasionalisasi LKM nantinya, misalnya lingkup 1 RW, 1 Desa, dan lebih luas lagi atau bisa lebih sempit. Ketiga, sosialisasi program kerja koperasi Syari'ah. Sebelum program kerja koperasi Syari'ah dilaksanakan, seluruh kader harus melakukan sosialisasi/penyuluhan kepada masyarakat.

Tujuannya adalah agar masyarakat tahu bahwa di wilayah tersebut sedang dibentuk koperasi Syari'ah khusus untuk masyarakat disana. Selain itu, kegiatan sosialisasi ini juga ditujukan agar masyarakat mengetahui apa keuntungan dari adanya koperasi Syari'ah dan bagaimana teknis kerja koperasi tersebut di masyarakat nanti.

Biasanya tahap ini yang membutuhkan waktu yang cukup lama, tergantung dari cara sosialisasi yang dilakukan dan biasanya tidak seluruh masyarakat dengan mudah menyetujui dan bersedia ikut berpartisipasi dengan adanya koperasi Syari'ah ini. Sosialisasi kerja oleh kader koperasi dilakukan dengan teknik penyuluhan massal melalui kegiatan pengajian majelis ta'lim, acara-acara keagamaan besar, atau dengan cara persuasif (door to door). Keempat, penghimpunan dana dari masyarakat.

Pengumpulan dana ini tentu saja tidak sekadar dikumpulkan dalam bentuk infak semata melainkan juga dalam bentuk simpanan masyarakat. Kader-kader koperasi Syari'ah menggunakan pelbagai macam cara untuk menghimpun dana dari masyarakat. Misalnya melalui sistem jempitan atau perelek.

Sistem jempitan atau perelek adalah suatu sistem pengumpulan dana dengan menggunakan gelas plastik air mineral bekas yang telah ditempeli dengan label nama koperasi Syari'ah, dan dipasang di dinding depan atau dinding dalam rumah setiap warga. Gelas plastik berlabel tersebut akan diisi oleh warga dengan nominal dana sesuai kemampuan dan kehendak warga tersebut. Selanjutnya dana yang telah dimasukkan ke dalam gelas plastik bekas 
tersebut diambil dan dikumpulkan secara rutin oleh kaderkader koperasi dalam jangka waktu yang ditentukan.

Sebelumnya, kader-kader koperasi pun telah menyediakan sistem pembukuan sederhana untuk menuliskan jumlah dana yang diambil dari setiap rumah warga dan setiap warga pun memiliki buku catatan mini untuk pegangan masing-masing. Penghimpunan dana ini dilakukan secara terus-menerus dan berkelanjutan agar warga masyarakat dapat membiasakan dirin menabung.

Kelima, penyaluran dana kepada masyarakat. Setelah kegiatan pengumpulan dana berjalan dalam beberapa waktu dan dipandang sudah cukup untuk dijadikan permodalan koperasi Syari'ah bagi masyarakat, seluruh kader mengumumkan dengan cara yang sama pada tahap sosialisasi, agar masyarakat yang membutuhkan permodalan bisa mulai untuk meminjam modal. Penyaluran modal tidak bisa dilakukan secara sembarangan, akan tetapi harus sesuai dengan aturan Syari'ah yakni melalui akad dan aturan kerjasama (syirkah) dan bagi hasil keuntungan yang disepakati bersama. Penerima pembiayaanan modal dapat dilakukan dengan cara murabahah, mudharabah, musyarakah, dan istisna.

Pada tahap ini, koperasi Syari'ah sudah memiliki sistem pembukuan yang memadai sehingga tidak terjadi kesalahan dalam penyaluran modal. Acapkali selain untuk permodalan (sistem syirkah), masyarakat juga membutuhkan dana untuk keperluan darurat seperti membayar biaya rumah sakit, dan lain-lain. Koperasi Syari'ah pun dapat ikut membantu meminjamkan dana dengan pola Qardul Hasan, dengan tidak menetapkan bagi hasil usaha atau bunga akan tetapi tetap menggunakan tata cara pembayaran yang sama seperti halnya penerima pembiayaanan modal.

Keenam, pengawasan usaha dan pelunasan dana yang dipinjam. Pengawasan usaha dilakukan secara transparan oleh kedua belah pihak. Pihak penerima pembiayaan harus jujur dalam melaporkan perkembangan usaha dan pihak koperasi harus melakukan pembukuan yang baik terkait dengan perkembangan usaha. Sedangkan dalam pelunasan modal yang dipinjam beserta bagi hasil yang disepakati, pembayarannya harus sesuai dengan cara dan jangka waktu yang disepakati di awal perjanjian. Jika tejadi kemacetan dalam pembayaran, pihak koperasi tidak boleh memberatkan penerima pembiayaan.

Biasanya, pihak koperasi akan menentukan denda atau infaq jika pihak penerima pembiayaan tidak bisa membayar tepat waktu, sedangkan untuk pelunasan selanjutnya tetap menggunakan cara dan dengan jangka waktu yang sama. Adanya LKM Syariah ini tentu bisa dijadikan solusi bagi permasalahan ekonomi di masyarakat dan pelaksanaanya pun bisa dilakukan secara swadaya dan mandiri oleh masyarakat itu sendiri. Pembentukan LKM Syariah bisa dilakukan oleh masyarakat dari berbagai kalangan yang ingin secara mandiri membentuk LKM Syariah untuk keperluan mereka.

Dengan adanya LKM Syariah, masyarakat bisa lebih mandiri dan secara berkelanjutan meningkatkan semangat kerja sama mereka dan bahu-membahu serta saling membantu antara warga yang satu dengan warga yang lain. LKM Syari'ah yang mampu berkembang dan membutuhkan modal yang besar dalam menyalurkan pembiayaan kepada masyarakat (nasabah), bisa mencari Lembaga Perbankan Syariah sebagai induk yang bisa memberikan tambahan modal dengan mengikuti aturan yang mereka buat.

Dengan begitu, sistem ekonomi Syari'ah bisa terus diterapkan dengan harapan jangka panjangnya, sistem ini mampu meningkatkan berbagai usaha dalam sektor riil yang ada di berbagai level masyarakat untuk mencapai kemaslahatan bersama.

\section{KESIMPULAN}

Kegiatan pengabdian kepada masyarakat dengan tema “Pemberdayaan Ibu-Ibu Jamaah Majelis Ta'lim Melalui Pelatihan Kewirausahaan Syari'ah di Desa Balokang Kota Banjar Propinsi Jawa Barat" berhasil meningkatkan pengetahuan pemahaman dan wawasan ibu-ibu jamaah Majelis Ta'lim sehingga mereka memiliki kesadaran untuk bermu'amalah secara syari'ah. Karena kesadaran telah muncul dalam diri ibu-ibu jamaah Majelis Ta'lim maka upaya untuk mendirikan lembaga keuangan mikro (LKM) syari'ah pun menjadi lebih mudah dilaksanakan. Dengan menggunakan metode participatory action research (PAR) kegiatan pengabdian ini berhasil merintis berdirinya lembaga keuangan mikro syari'ah di Desa Balokang Kota Banjar Propinsi Jawa Barat..

\section{DAFTAR PUSTAKA}

Badriah 2000 Peranan Wanita Tangse dalam Sosial ekonomi Rumah Tangga: Suatu Kajian di Desa Krueng Seukeuk Banda Aceh Ringkasan Hasil Penelitian STIES.

BPS 2002 Aceh dalam Angka 2001 Banda Aceh: PBS dan Bappeda Provinsi NAD.

Biro PP Setda NAD 2002 Profil Jender Provinsi Nanggroe Aceh Darussalam Banda Aceh: Biro Pemberdayaan Perempuan Setda Provinsi Nanggroe Aceh Darussalam.

Hasan CA 2001 Efektifitas Pendistribusian Dana Modal Kerja pada Wanita Janda Ekses DOM di Aceh Jakarta: Kantor Menteri Pemberdayaan Perempuan Rl.

Lindsey LL 1990 Gender Role: a Sociological Perspective New Jersey: Prentice Hall. 
Moersidin Mukhlas 2000 Konflik Politik: Sumber Bencana Bagi Kehidupan Rakyat Aceh Banda Aceh: Ringkasan Hasil Penelitian.

Nyak Pha MH 1994 Wanita Aceh dan Peranannya Banda Aceh: Ringkasan Hasil Penelitian STIES.

Nasution S 1988 Penelitian Naturalistik Kualitatif Bandung Tarsito.

Nye IF 1976 Role Structure and Analysis of the Family California: Sage Library of Social Research.

Pudjiwati S 1993 Peran Wanita dalam Perkembangan Masyarakat Desa Jakarta: Rajawali Pers.

Saptari R 1997 Perempuan Kerja dan Perubahan Sosial Jakarta: Grafiti.

Syah AF 2003 Gender dalam Perspektif Agama-Agama Banda Aceh: CV. Hasanah.

Tavris C 1992 Mismeasure of Woman New York: Touchstone..

UNESA. 2000. Pedoman Penulisan Artikel Jurnal, Surabaya: Lembaga Penelitian Universitas Negeri Surabaya.

Wahab, Abdul dan Lestari, Lies Amin. 1999. Menulis Karya Ilmiah. Surabaya: Airlangga University Press.

Winardi, Gunawan. 2002. Panduan Mempersiapkan Tulisan Ilmiah. Bandung: Akatiga. 